\title{
NOTE
}

\section{Sawfish (Pristidae) records along the Eastern Amazon coast}

\author{
Leonardo Manir Feitosa ${ }^{1, *}$, Ana Paula Barbosa Martins ${ }^{2}$, Jorge Luiz Silva Nunes ${ }^{3}$ \\ ${ }^{1}$ Laboratório de Genética e Biologia Molecular, Departamento de Biologia, Universidade Federal do Maranhão, \\ Cidade Universitária do Bacanga, 65080-805 São Luís, Maranhão, Brazil \\ ${ }^{2}$ Centre for Sustainable Tropical Fisheries and Aquaculture, College of Science and Engineering, James Cook University, \\ Townsville, QLD 4811, Australia \\ ${ }^{3}$ Departamento de Oceanografia e Limnologia, Universidade Federal do Maranhão, Cidade Universitária do Bacanga, \\ 65080-805 São Luís, Maranhão, Brazil
}

\begin{abstract}
Sawfishes are the most endangered cartilaginous fishes on the planet. Their external morphology facilitates entanglement in fishing nets and their $K$-selected life history hinders the recovery of exploited populations. The Eastern Amazon coast (EAC) is known to be an area where sawfishes occur in Brazil, but few studies have been conducted in the area to better understand their biology and ecology. The present study reports sawfish captures along the coast of Brazil's second largest state. Data were collected from interviews with fishermen, a literature review, and media reports. In total, 23 captures were recorded between 1984 and 2016. Records include adults, a pregnant female with near-term embryos, juveniles, and young-of-the-year specimens. Most catches were reported in the Canal do Navio, an area under strong human pressure. Sawfish saws are valuable items and, for many anglers in precarious economic and social situations, high market prices eclipse the fishing prohibitions laid down under federal laws. Urgent research is required to understand sawfishes' life history, identify their critical habitats, and effectively manage and conserve these species along the EAC.
\end{abstract}

KEY WORDS: Sawfish · Pristidae $\cdot$ Artisanal fisheries $\cdot$ Conservation $\cdot$ Amazon coast

\section{INTRODUCTION}

Sawfishes are large cartilaginous fishes, easily recognized by an enlarged rostrum shaped as a saw. They are distributed across coastal areas, estuaries, and freshwaters from tropical to subtropical regions - especially in shallow, sandy, or muddy bottoms. The saw is used mainly for feeding purposes, such as to scour the bottom for benthic prey or to capture free-swimming ray-finned fishes (Wueringer et al. 2012, Poulakis et al. 2017). However, rostral expansion is also the main

*Corresponding author: lmfeitos@gmail.com cause of entanglement in fishing nets (Dulvy et al. 2016).

Sawfish populations are extremely susceptible to fisheries exploitation due to their $K$-selected life history (e.g. late sexual maturation, low fecundity, and long lifespan) (Thorson 1976). Currently, Pristidae is the most threatened elasmobranch family in the world, with 3 of its 5 species considered Critically Endangered (Pristis pectinata, P. pristis, and P. zijsron) and the other 2 species considered Endangered (Anoxypristis cuspidata and P. clavata) (Dulvy et al. 2016).

() The authors 2017. Open Access under Creative Commons by Attribution Licence. Use, distribution and reproduction are unrestricted. Authors and original publication must be credited. 
In Brazil, only $P$. pristis and $P$. pectinata occur (Charvet \& Faria 2014). Their distribution seems to be restricted to northern areas of the country (Palmeira et al. 2013), where viable populations of sawfishes have been reported (Burgess et al. 2009, Charvet \& Faria 2014). Fishing of both species is prohibited by Brazilian legislation (IN 05, MMA 2004, www.mma.gov.br/estruturas/179/_arquivos/179_051 22008033927.pdf). However, they continue to be caught off the northern coast. Fisheries in this region are mainly artisanal with small to medium-sized vessels of little autonomy using mostly drift nets (Begossi et al. 2012). According to Pauly \& Zeller (2016), the fact that artisanal fisheries data are overlooked by regulating agencies leads to underestimation of catches, and is thus a major cause for the paucity of elasmobranch catch data worldwide, including the Brazilian coast.

The Brazilian Amazonian coast is comprised of highly productive and dynamic areas (e.g. coral reefs, estuaries, mangrove forests) (Giarrizzo et al. 2010, Moura et al. 2016). These areas provide habitat for sawfishes (Lessa et al. 1999) and several nationally endangered elasmobranch species, such as Isogomphodon oxyrhynchus (Lessa et al. 2016), Sphyrna mokarran, S. tudes, and S. lewini (Almeida et al. 2011). Fisheries in this region are mainly artisanal, whereas industrial fisheries are found only in southern Brazil (Bornatowski et al. 2014).

Since there are limited data available for artisanal fisheries in the area, local ecological knowledge (Anadón et al. 2009) becomes useful for directing future research. In addition, local knowledge is essential to the evaluation of critical habitat for endangered species in areas lacking in scientific data (ReisFilho et al. 2016). The present study aims to trace records of sawfish catches in the second largest coastal state of Brazil, Maranhão, through local ethnological knowledge, news reports, fisheries landings observations, and a literature review.

\section{MATERIALS AND METHODS}

\section{Study area}

Locally known as Reentrâncias Maranhenses, the Maranhão Amazon coast (MAC) area consists of several estuaries forming indented areas with mangrove-dominated channels (Lessa et al. 1999). MAC is a dynamic area, with macrotidal interference (4$7 \mathrm{~m}$ ). In addition, the region includes the largest area of mangrove forests in Brazil, comprising an esti- mated $5414.31 \mathrm{~km}^{2}$ (Souza-Filho 2005). The main mangrove species in the region are Rhizophora mangle, $R$. racemosa, $R$. harrissonii, Avicennia germinans, A. schaueriana, and Laguncularia racemosa. MAC has 2 distinct seasons: a wet season from January to June and a dry season from July to December. However, the average temperature year-round is $26^{\circ} \mathrm{C}$, regardless of season (Teixeira \& Souza-Filho 2009).

The Gulf of Maranhão (Fig. 1) is the most important zone of MAC, both socially and economically. The area is highly productive (Azevedo et al. 2008), consisting of 3 estuaries under the influence of strong currents (Teixeira \& Souza-Filho 2009). Fisheries in the MAC area are artisanal and target mainly the acoupa weakfish Cynoscion acoupa, tarpon Megalops atlanticus, and Brazilian Spanish mackerel Scomberomorus brasiliensis using drift nets (Lessa et al. 2016). Nutrient contents follow patterns observed for other rivers of the Amazon system, such as high organic matter input and turbidity (Azevedo et al. 2008). The Gulf of Maranhão suffers from pollution discharges from adjacent metropolitan areas (Silva et al. 2011). In addition, the gulf has a major channel (Canal do Navio) used for transportation of commodities through the Porto do Itaqui (one of the largest cargo ports of Brazil), with heavy and incessant traffic of cargo ships (www.emap.ma.gov.br/porto-do-itaqui/operacoesportuarias/movimentacao-de-carga).

\section{Data collection}

In January 2016 and 2017, eight traditional fishermen from the cities of Raposa and Vitória do Mearim where sawfish captures have been reported were interviewed using open questions regarding sawfish captures. Questions related to estimated total length (TL) and sex of the specimens, location and year of capture, and fishing gear used. Information about other areas of MAC was also provided by traditional fishermen from Raposa. These fishermen were considered qualified to provide data based on their knowledge acquired over decades of fishing across MAC and constant communication with fishermen from surrounding regions.

In addition, a literature review of published papers, books, and media reports about Maranhão State's elasmobranch fauna was carried out. Only records containing, at the least, capture location data were considered. Records of 2 rostra exposed in museum collections (Orla Viva NGO, a non-governmental organization and educational project for marine life conservation in São Luís, Maranhão) were also 


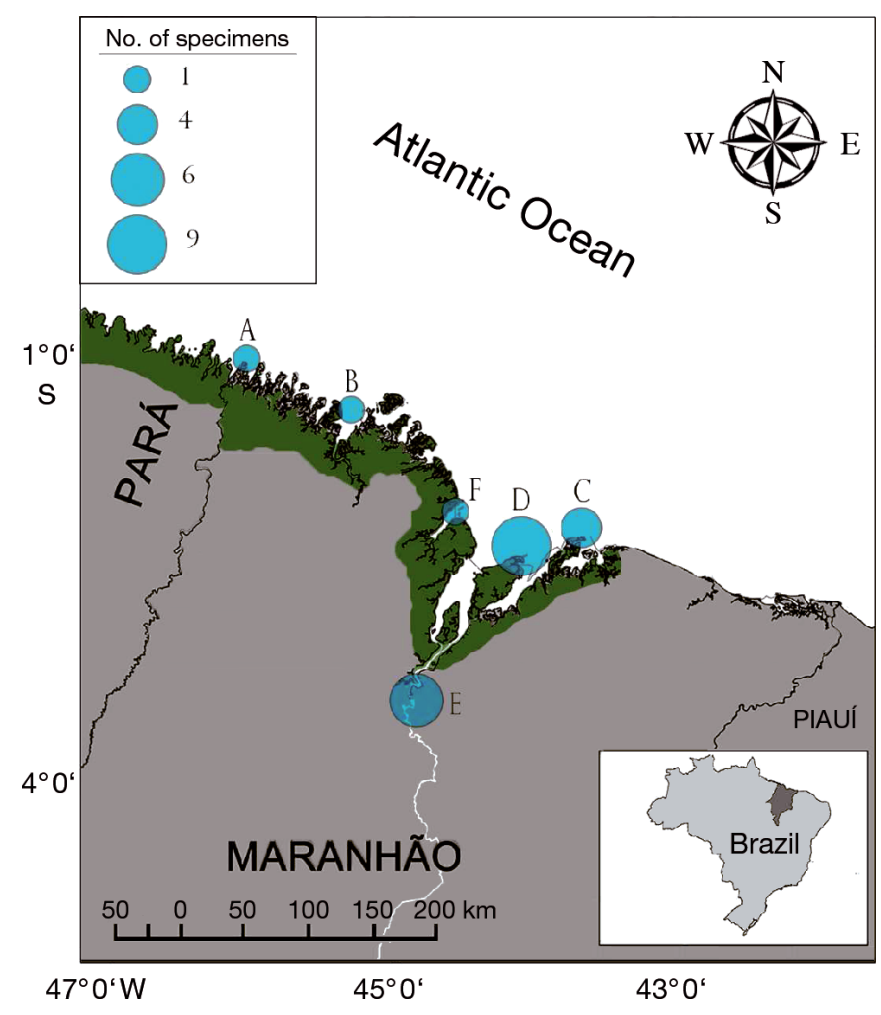

Fig. 1. Maranhão State coast (inset: Maranhão State within Brazil). Green shaded area is the Eastern Amazon coast, and the portion within Maranhão State territory is the Maranhão Amazon coast. Blue circles represent, proportionately to the number of records, probable places where sawfishes were captured and/or landed: A: Gurupi River mouth, B: Baia de Turiaçu, C: Farol de Santana, D: Canal do Navio, E: Mearim River, F: Baia de Cumã. White line: Mearim River the-year individuals (80 cm TL), juveniles $(100-300 \mathrm{~cm}$ TL), unsexed mature individuals (>300 cm TL), and 1 gravid female (Table 1). It is important to note that no record of Pristis pectinata was obtained among the identifiable specimens. Nine specimens (39\%) were reported from the Canal do Navio, at depths varying between 20 and $91 \mathrm{~m}$. Fourteen specimens were caught in other areas of MAC. The other locations were the Mearim River ( $\mathrm{n}=7 ; 30 \%$ ), Farol de Santana ( $\mathrm{n}=4 ; 17 \%)$, Baia de Turiaçu ( $\mathrm{n}=1 ; 4 \%)$, Baia de Cumã ( $\mathrm{n}=1 ; 4 \%)$, and the Gurupi River mouth $(\mathrm{n}=1$; $4 \%$ ) (Fig. 1). Records from the Farol de Santana consisted of 4 adult specimens of about $400 \mathrm{~cm}$ TL in 2010, the largest number of specimens caught in a single year among the records we obtained.

\section{DISCUSSION}

Sawfish populations are in decline worldwide (Dulvy et al. 2016). Data regarding where these elusive creatures have sustainable populations are scarce (Fernandez-Carvalho et al. 2014). Conservation concerns in our study area arise due to the proximity of the sawfish capture points to the coast and human settlements. Human demographic growth in the region has been intense and has compromised much of the local ecosystem. Thus, sawfish stocks across the MAC are often subjected to habitat degradation as a result of mangrove deforestation, pollution (Silva et al. 2011), and strong artisanal fishing pressures. Areas such as the Canal do Navio, where 3 juvenile included in this analysis. Standard rostrum length was measured and TL estimated following Whitty et al. (2014). Specimens were identified following Faria et al. (2013). Life stage was estimated based on specimens' TL: birth $(72-90 \mathrm{~cm})$, juvenile $(91-280 \mathrm{~cm})$, and adult size $(>280 \mathrm{~cm}$ ) (Last et al. 2016).

\section{RESULTS}

Between 1984 and 2016, a total of 23 sawfish catches were recorded in the study area. Specimens varied in size between 80 and $700 \mathrm{~cm}$ TL (Figs. 2 \& 3; see also Fig. S1 in the Supplement at www.int-res.com/articles/suppl/n034 p229_supp.pdf), comprising young-of-
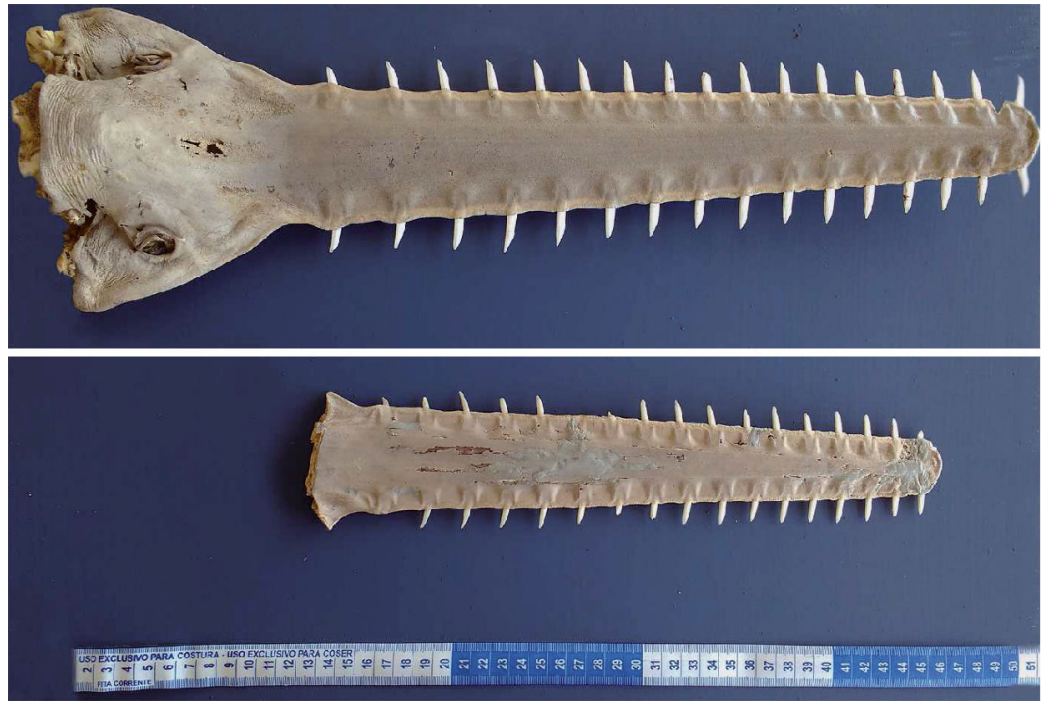

Fig. 2. Juvenile (top photo; captured 2016) and young-of-the-year (bottom photo; captured 2007) Pristis pristis rostra in Orla Viva NGO's collection of fauna specimens from the coast of Maranhão 


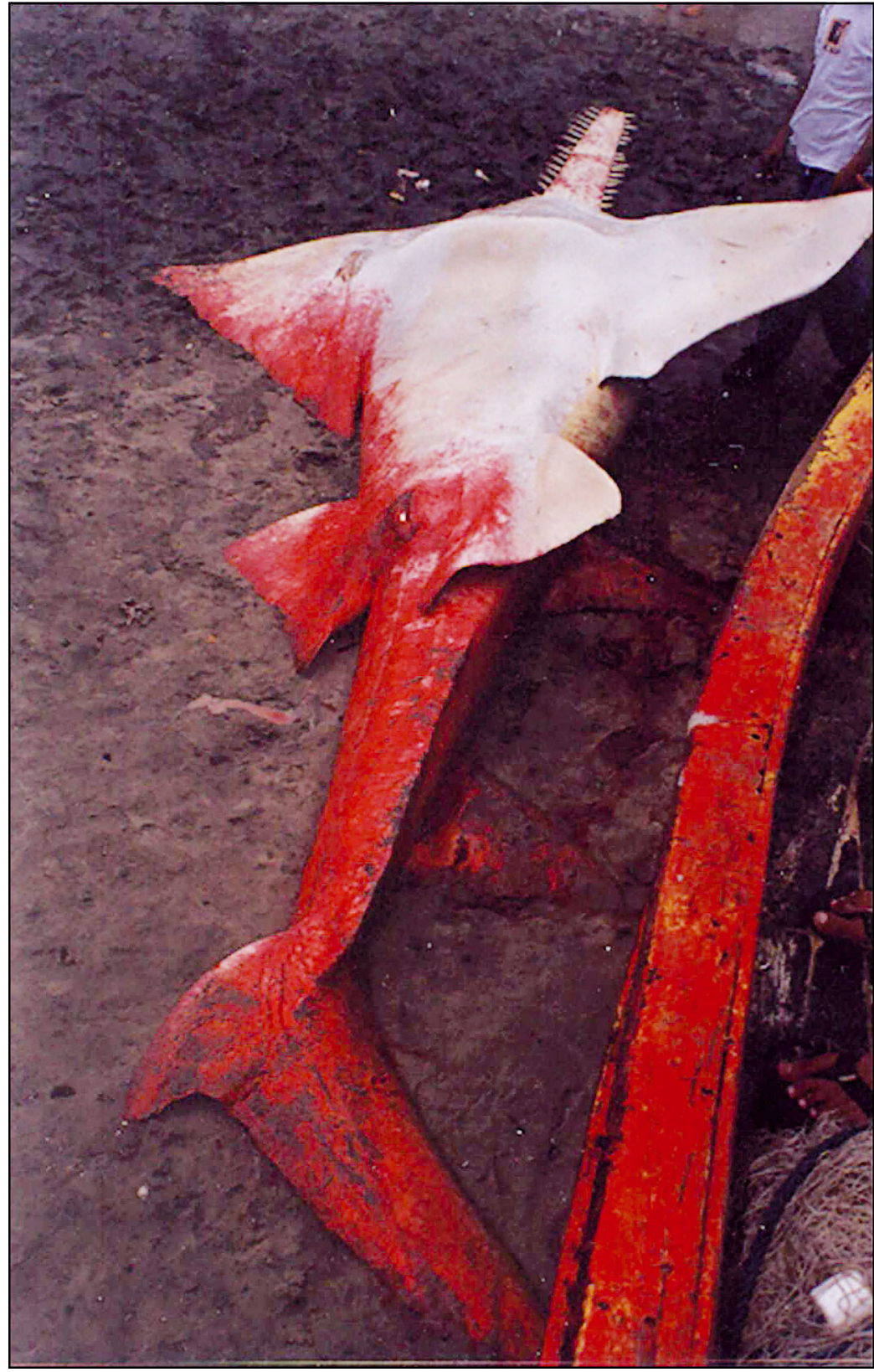

Fig. 3. Largest Pristis pristis female caught in the area to date (estimated total length: $700 \mathrm{~cm}$ ). The individual was captured in 1998

specimens and a gravid female were caught, and Mearim River, where all catches consisted of juveniles, should be recognized as priority areas for research and conservation purposes. Despite the lack of data on sawfish biology and ecology, and the absence of continuous fishery-independent surveys in these areas, as recommended by Heupel et al. (2007), our data suggest that the Canal do Navio and the Mearim River might be potential nursery grounds for sawfish along the Amazon coast.
Present data demonstrate the ongoing practice of environmental crimes by the fishing communities of Maranhão State. This occurs mainly due to the lack of inspection both on board fishing vessels and at their landing points. Moreover, artisanal fishing in the MAC area is practiced by economically deprived people with little or no education. Since sawfish saws are extremely valuable as collection pieces, often being sold for more than US\$800 (Charvet-Almeida \& Faria 2008), fishermen are easily impelled to commercialize these items, even though they recognize and fear the illegality of the act. Nevertheless, one exception to the lack of law enforcement occurred. The fisherman responsible for the capture of a large adult specimen in 2015 (Fig. S1 in the Supplement) suffered the punishment required by Brazilian law, being fined approximately US\$9000 (current exchange rate) for illegal fisheries. According to interviewed anglers, a group of fishermen, fearing the same consequences, released alive a large sawfish specimen caught later in the same year and area. Fin trade, on the other hand, was not reported by the interviewees, although the removal of pectoral fins was observed photographically (Fig. S2 in the Supplement). In general, little has been done by regulatory agencies to manage and protect sawfish stocks or their habitat.

Preservation of the natural environments that function as remote refuges for sawfish species present a great challenge. Conservation initiatives are overwhelmed by increasing fishing pressure, habitat destruction caused by urban development, lack of oversight by regulatory agencies, and critical social issues. We therefore endorse the need for urgent research here. Genetic diversity, population size, sex ratio, movement patterns, habitat use, and trophic ecology data are crucial to fully understand sawfishes and thus establish policy measures to protect their populations in the MAC and Eastern Amazon coast (EAC) areas. 
Table 1. Time series (1984-2016) of sawfish catches obtained through interviews with fishermen, a literature review, the Orla Viva collection (a non-governmental organization and educational project for marine life conservation in São Luís, Maranhão), and observation of fisheries landings along the Maranhão Amazon coast. All specimens were caught with drift gill nets by entanglement. na: not available, TL: total length

\begin{tabular}{|c|c|c|c|c|c|c|c|c|}
\hline Year & Municipality & Location & $\begin{array}{l}\text { Geographic } \\
\text { coordinates }\end{array}$ & Sex & $\begin{array}{l}\text { Estimated } \\
\text { TL }(\mathrm{cm})\end{array}$ & $\begin{array}{l}\text { Maturity } \\
\text { stage }\end{array}$ & Species & $\begin{array}{l}\text { Data } \\
\text { source }\end{array}$ \\
\hline 1984 & Guimarães & $\begin{array}{l}\text { Baia de Cumã, } \\
\text { Gulf of Maranhão }\end{array}$ & $2^{\circ} 35^{\prime} \mathrm{S}, 44^{\circ} 1^{\prime} \mathrm{W}$ & na & 80 & Juvenile & $\begin{array}{l}\text { Pristis } \\
\text { pristis }\end{array}$ & Lessa (1986) \\
\hline 1985 & Raposa & $\begin{array}{l}\text { Canal do Navio, } \\
\text { Gulf of Maranhão }\end{array}$ & $2^{\circ} 15^{\prime} \mathrm{S}, 44^{\circ} 8^{\prime} \mathrm{W}$ & na & na & Adult & Pristis sp. & Interview \\
\hline 1991 & Raposa & $\begin{array}{l}\text { Canal do Navio, } \\
\text { Gulf of Maranhão }\end{array}$ & $2^{\circ} 15^{\prime} \mathrm{S}, 44^{\circ} 8^{\prime} \mathrm{W}$ & na & 454 & Adult & P. pristis & $\begin{array}{l}\text { Stride et al. } \\
\text { (1992) }\end{array}$ \\
\hline 1998 & Raposa & $\begin{array}{l}\text { Canal do Navio, } \\
\text { Gulf of Maranhão }\end{array}$ & $2^{\circ} 15^{\prime} \mathrm{S}, 44^{\circ} 8^{\prime} \mathrm{W}$ & Female & 700 & Adult & P. pristis & Almeida (1999) \\
\hline 1999 & Arari & Mearim River & $3^{\circ} 27^{\prime} \mathrm{S}, 44^{\circ} 47^{\prime} \mathrm{W}$ & Female & 170 & Juvenile & P. pristis & Soares (2005) \\
\hline 2007 & Raposa & $\begin{array}{l}\text { Canal do Navio, } \\
\text { Gulf of Maranhão }\end{array}$ & $2^{\circ} 15^{\prime} \mathrm{S}, 44^{\circ} 8^{\prime} \mathrm{W}$ & na & 80 & Juvenile & P. pristis & Orla Viva \\
\hline 2009 & Raposa & $\begin{array}{l}\text { Canal do Navio, } \\
\text { Gulf of Maranhão }\end{array}$ & $2^{\circ} 15^{\prime} \mathrm{S}, 44^{\circ} 8^{\prime} \mathrm{W}$ & Female & 500 & Pregnant & P. pristis & $\begin{array}{l}\text { Nunes et al. } \\
\text { (2016) }\end{array}$ \\
\hline 2009 & Raposa & $\begin{array}{l}\text { Canal do Navio, } \\
\text { Gulf of Maranhão }\end{array}$ & $2^{\circ} 15^{\prime} \mathrm{S}, 44^{\circ} 8^{\prime} \mathrm{W}$ & Male & 500 & Adult & Pristis sp. & Interview \\
\hline 2009 & Arari & Mearim River & $3^{\circ} 27^{\prime} \mathrm{S}, 44^{\circ} 47^{\prime} \mathrm{W}$ & na & 120 & Juvenile & Pristis sp. & Interview \\
\hline 2010 & $\begin{array}{l}\text { Humberto } \\
\text { de Campos }\end{array}$ & $\begin{array}{l}\text { Farol de Santana, } \\
\text { Gulf of Maranhão }\end{array}$ & $2^{\circ} 17^{\prime} \mathrm{S}, 43^{\circ} 43^{\prime} \mathrm{W}$ & na & 400 & Adult & Pristis sp. & Interview \\
\hline 2010 & $\begin{array}{l}\text { Humberto } \\
\text { de Campos }\end{array}$ & $\begin{array}{l}\text { Farol de Santana, } \\
\text { Gulf of Maranhão }\end{array}$ & $2^{\circ} 17^{\prime} \mathrm{S}, 43^{\circ} 43^{\prime} \mathrm{W}$ & na & 400 & Adult & Pristis sp. & Interview \\
\hline 2010 & $\begin{array}{l}\text { Humberto } \\
\text { de Campos }\end{array}$ & $\begin{array}{l}\text { Farol de Santana, } \\
\text { Gulf of Maranhão }\end{array}$ & $2^{\circ} 17^{\prime} \mathrm{S}, 43^{\circ} 43^{\prime} \mathrm{W}$ & na & 400 & Adult & Pristis sp. & Interview \\
\hline 2010 & $\begin{array}{l}\text { Humberto } \\
\text { de Campos }\end{array}$ & $\begin{array}{l}\text { Farol de Santana, } \\
\text { Gulf of Maranhão }\end{array}$ & $2^{\circ} 17^{\prime} \mathrm{S}, 43^{\circ} 43^{\prime} \mathrm{W}$ & na & 400 & Adult & Pristis sp. & Interview \\
\hline 2012 & Raposa & $\begin{array}{l}\text { Canal do Navio, } \\
\text { Gulf of Maranhão }\end{array}$ & $2^{\circ} 15^{\prime} \mathrm{S}, 44^{\circ} 8^{\prime} \mathrm{W}$ & na & na & Adult & Pristis sp. & Interview \\
\hline 2012 & Vitória do Mearim & Mearim River & $3^{\circ} 27^{\prime} \mathrm{S}, 44^{\circ} 52^{\prime} \mathrm{W}$ & na & 130 & Juvenile & P. pristis & Exposed rostrum \\
\hline 2014 & Turiaçu & Baia de Turiaçu & $1^{\circ} 33^{\prime} \mathrm{S}, 45^{\circ} 17^{\prime} \mathrm{W}$ & na & na & Juvenile & Pristis sp. & Interview \\
\hline 2015 & Raposa & $\begin{array}{l}\text { Canal do Navio, } \\
\text { Gulf of Maranhão }\end{array}$ & $2^{\circ} 15^{\prime} \mathrm{S}, 44^{\circ} 8^{\prime} \mathrm{W}$ & na & 500 & Adult & Pristis sp. & Media report \\
\hline 2015 & Raposa & $\begin{array}{l}\text { Canal do Navio, } \\
\text { Gulf of Maranhão }\end{array}$ & $2^{\circ} 15^{\prime} \mathrm{S}, 44^{\circ} 8^{\prime} \mathrm{W}$ & na & na & Adult & Pristis sp. & Interview \\
\hline 2015 & Carutapera & $\begin{array}{l}\text { Gurupi River } \\
\text { mouth }\end{array}$ & $1^{\circ} 1^{\prime} \mathrm{S}, 46^{\circ} 1^{\prime} \mathrm{W}$ & na & na & Adult & Pristis sp. & Interview \\
\hline 2016 & Vitória do Mearim & Mearim River & $3^{\circ} 27^{\prime} \mathrm{S}, 44^{\circ} 52^{\prime} \mathrm{W}$ & na & 114 & Juvenile & P. pristis & Exposed rostrum \\
\hline 2016 & Vitória do Mearim & Mearim River & $3^{\circ} 27^{\prime} \mathrm{S}, 44^{\circ} 52^{\prime} \mathrm{W}$ & na & 110 & Juvenile & P. pristis & Exposed rostrum \\
\hline 2016 & Vitória do Mearim & Mearim River & $3^{\circ} 27^{\prime} \mathrm{S}, 44^{\circ} 52^{\prime} \mathrm{W}$ & na & 152 & Juvenile & P. pristis & Exposed rostrum \\
\hline 2016 & Anajatuba & Mearim River & $2^{\circ} 15^{\prime} \mathrm{S}, 44^{\circ} 8^{\prime} \mathrm{W}$ & na & 139 & Juvenile & P. pristis & Orla Viva \\
\hline
\end{tabular}

Acknowledgements. We thank the fishermen who agreed to be interviewed, Orla Viva NGO for allowing data collection, FAPEMA, São Luís, Maranhão, for providing a productive scholarship, and Patrício Getúlio Garcia Neto for figure preparation.

\section{LITERATURE CITED}

Almeida ZS (1999) Levantamento e ocorrência de elasmobrânquios capturados pela pesca artesanal no litoral do Maranhão. Bol Soc Brasil Estud Elasmobrânquios (SBEEL) 4:10
Almeida ZS, Fredou FL, Nunes JLS, Lessa RPT, Pinheiro ALR (2011) Biodiversidade de elasmobrânquios. In: Nunes JLS, Piorski NM (eds) Peixes marinhos e estuarinos do Maranhão. Café e Lápis, São Luís, p 37-94

Anadón JD, Giménez A, Ballestar R, Pérez I (2009) Evaluation of local ecological knowledge as a method for collecting extensive data on animal abundance. Conserv Biol 23:617-625

Azevedo ACGD, Feitosa FAN, Koening ML (2008) Distribuição espacial e temporal da biomassa fitoplanctônica e variáveis ambientais no Golfão Maranhense, Brasil. Acta Bot Bras 22:870-877 
Begossi A, Lopes P, Silvano R (2012) Co-management of reef fisheries of the snapper-grouper complex in a human ecological context in Brazil. In: Kruse GH, Browman HI, Cochrane KL, Evans D and others (eds) Global progress in ecosystem-based fisheries management. Alaska Sea Grant, University of Alaska, Fairbanks, AK, p 353-374

Bornatowski H, Braga RR, Vitule JRS (2014) Threats to sharks in a developing country: the need for effective simple conservation measures. Nat Conserv 12:11-18

Burgess GH, Carvalho JF, Imhoff JL (2009) An evaluation of the status of the largetooth sawfish, Pristis perotteti, based on historic and recent distribution and qualitative observations of abundance. Florida Museum of Natural History, Gainesville, FL

Charvet P, Faria VV (2014) Geographical distribution and status: Southwest Atlantic Ocean. In: Harrison LR, Dulvy NK (eds) Sawfish: a global strategy for conservation. IUCN Species Survival Commission's Shark Specialist Group, Vancouver, p 48-49

Charvet-Almeida P, Faria VV (2008) Pristis perotteti. In: Machado ABM, Drummond GM, Paglia AP (eds) Livro vermelho da fauna Brasileira ameaçada de extinção. Série biodiversidade, Vol II. Fundação Biodiversitas, Belo Horizonte, p 33-35

Dulvy NK, Davidson LN, Kyne PM, Simpfendorfer CA, Harrison LR, Carlson JK, Fordham SV (2016) Ghosts of the coast: global extinction risk and conservation of sawfishes. Aquat Conserv 26:134-153

Faria VV, McDavitt MT, Charvet P, Wiley TR, Simpfendorfer CA, Naylor GJ (2013) Species delineation and global population structure of Critically Endangered sawfishes (Pristidae). Zool J Linn Soc 167:136-164

Fernandez-Carvalho J, Imhoff JL, Faria VV, Carlson JK, Burgess GH (2014) Status and the potential for extinction of the largetooth sawfish in the Atlantic Ocean. Aquat Conserv 24:478-497

Giarrizzo T, Krumme U, Wosniok W (2010) Size-structured migration and feeding patterns in the banded puffer fish Colomesus psittacus (Tetraodontidae) from north Brazilian mangrove creeks. Mar Ecol Prog Ser 419:157-170

Heupel MR, Carlson JK, Simpfendorfer CA (2007) Shark nursery areas: concepts, definition, characterization and assumptions. Mar Ecol Prog Ser 337:287-297

Last P, White W, Séret B, Naylor G, de Carvalho M, Stehmann M (eds) (2016) Rays of the world. CSIRO Publishing, Clayton South

Lessa RP (1986) Levantamento faunístico dos elasmobrânquios (Pisces, Chondrichthyes) do litoral ocidental do estado do Maranhão, Brasil. Bol Lab Hidrobiol 7:27-41

Lessa R, Santana FM, Rincón G, Gadig OBF, El-Deir ACA (1999) Biodiversidade de elasmobrânquios do Brasil. Programa Nacional da Diversidade Biológica (PRONABIO), Ministério do Meio Ambiente (MMA), Recife

Lessa R, Batista VS, Santana FM (2016) Close to extinction?

Editorial responsibility: Dean Grubbs (Guest Editor), St. Teresa, Florida, USA
The collapse of the endemic daggernose shark (Isogomphodon oxyrhynchus) off Brazil. Glob Ecol Conserv 7: 70-81

Moura RL, Amado-Filho GM, Moraes FC, Brasileiro PS and others (2016) An extensive reef system at the Amazon River mouth. Sci Adv 2:e1501252

Nunes JLS, Rincon G, Piorski NM, Martins APB (2016) Near term embryos in a Pristis pristis (Elasmobranchii: Pristidae) from Brazil. J Fish Biol 89:1112-1120

* Palmeira CAM, Rodrigues-Filho LSF, Sales JBL, Vallinoto M, Schneider H, Sampaio I (2013) Commercialization of a critically endangered species (largetooth sawfish, Pristis perotteti) in fish markets of northern Brazil: authenticity by DNA analysis. Food Contr 34:249-252

*Pauly D, Zeller D (2016) Catch reconstructions reveal that global marine fisheries catches are higher than reported and declining. Nat Commun 7:10244

*Poulakis GR, Urakawa H, Stevens PW, DeAngelo JA and others (2017) Sympatric elasmobranchs and fecal samples provide insight into the trophic ecology of the smalltooth sawfish. Endang Species Res 32:491-506

* Reis-Filho JA, Freitas RHA, Loiola M, Leite L and others (2016) Traditional fisher perceptions on the regional disappearance of the largetooth sawfish Pristis pristis from the central coast of Brazil. Endang Species Res 29:189-200

Silva IR, Pereira LCC, Oliveira SMO, Guimarães DO, Sousa RC, Costa RMDA (2011) Amazon beaches (São Luís, Brazil): recreational use, environmental indicators, and perception of beachgoers. J Coast Res Spec Issue 64: 1287-1291

Soares EC (2005) Peixes do Mearim. Instituto Geia, São Luís

* Souza Filho PWM (2005) Costa de manguezais de macromaré da Amazônia: cenários morfológicos, mapeamento e quantificação de áreas usando dados de sensores remotos. Rev Bras Geofís 23:427-435

Stride KR, Batista VS, Raposo LA (1992) Pesca experimental de tubarão com redes de emalhar no litoral maranhense. EDUFMA, São Luís

* Teixeira SG, Souza Filho PWM (2009) Mapeamento de ambientes costeiros tropicais (Golfão Maranhense, Brasil) utilizando imagens de sensores remotos orbitais. Rev Bras Geofís 27:69-82

Thorson TB (1976) Observations on the reproduction of the sawfish, Pristis perotteti, in Lake Nicaragua, with recommendations for its conservation. In: Thorson TB (ed) Investigations of the ichthyofauna of Nicaraguan lakes. University of Nebraska, Lincoln, NE, p 641-650

Whitty JM, Phillips NM, Thorburn DC, Simpfendorfer CA, Field I, Peverell SC, Morgan DL (2014) Utility of rostra in the identification of Australian sawfishes (Chondrichthyes:Pristidae). Aquat Conserv 24:791-804

*Wueringer BE, Squire L, Kajiura SM, Hart NS, Collin SP (2012) The function of the sawfish's saw. Curr Biol 22: R150-R151

Submitted: October 2, 2016; Accepted: July 7, 2017

Proofs received from author(s): August 30, 2017 